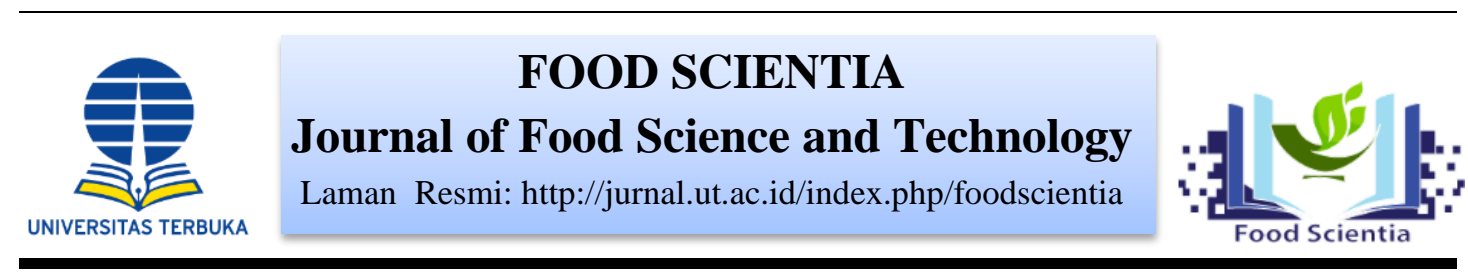

\title{
ANALISA KUALITATIF FORMALIN PADA SAMPEL IKAN ASIN DI PASAR SEDERHANA KOTA BANDUNG
}

\author{
Formalin Qualitative Analysis on Salted Fish Samples \\ in Sederhana Market of Bandung \\ Lusi Noorrela ${ }^{1}$, Indra Putra Munggaran ${ }^{2}$ \\ 1,2Balai Besar Pengawasan Obat dan Makanan (BBPOM Bandung) \\ Jalan Pasteur, Pasir Kaliki, Bandung, Jawa Barat, 40171, Indonesia \\ e-mail : lusinoorrela@gmail.com
}

DOI: $10.33830 /$ fsj.v1i1.1332.2021

Diterima: 25 Februari 2021, Diperbaiki:27 Mei 2021, Disetujui: 10 Juni 2021

\begin{abstract}
Salted fish is one of the most nutritious foods consumed in Indonesia but it is very prone to spoilage. Due to the speed of decomposition of salted fish, many traders use formaldehyde as a preservative for salted fish. Regulation of the Minister of Health of the Republic of Indonesia Number 1168 / Menkes / PER / X / 1999 states that formalin is a preservative that is prohibited from being used as a food preservative because it can cause damage to the digestive tract, liver and lungs, and can even cause cancer. The purpose of this study was to identify the formaldehyde content in salted fish sold in the Sederhana Market in Bandung. This research was conducted by taking samples at the Sederhana Market in Bandung. Qualitative analysis of formaldehyde was carried out at the Chemical Testing Laboratory of Balai Besar Pengawas Obat dan Makanan in Bandung in October 2020. Formalin identification of 25 fish samples was done colorimetrically using the MERCK test kit. Based on the grouping of salted fish, positive results were obtained by $20 \%$ for Salted Anchovies and $100 \%$ for Salted Cucut Fish, while Salted Kapas Fish, Salted Squid, and Salted Sepat Fish did not contain formaldehyde. The conclusion of this study is that $24 \%$ of salted fish taken from the Bandung Sederhana Market was positive for formaldehyde. The group that contains the most formalin is Salted Cucut Dish.
\end{abstract}

Keywords : formaldehyde, salted fish, safety food, traditional market

\begin{abstract}
ABSTRAK
Ikan asin merupakan salah satu makanan dengan sumber nutrisi lengkap yang paling banyak dikonsumsi di Indonesia namun sangat mudah mengalami pembusukan. Cepatnya proses pembusukan pada ikan asin mengakibatkan banyaknya pedagang yang menggunakan formalin sebagai pengawet ikan asin. Peraturan Menteri Kesehatan Republik Indonesia Nomor 1168/Menkes/PER/X/1999 menyatakan bahwa formalin merupakan bahan pengawet yang dilarang untuk digunakan sebagai pengawet makanan karena dapat menyebabkan kerusakan pada saluran pencernaan, ginjal, hati dan paru-paru, bahkan dapat menyebabkan
\end{abstract}


kanker. Tujuan dari penelitian ini untuk mengidentifikasi kandungan formalin pada ikan asin yang dijual di Pasar Sederhana Kota Bandung. Penelitian ini dilaksanakan dengan pengambilan sampel ikan asin di Pasar Sederhana Kota Bandung. Pengujian analisa kualitatif formalin dilaksanakan di Laboratorium Bidang Pengujian Kimia Balai Besar Pengawas Obat dan Makanan di Bandung pada Oktober 2020. Dilakukan identifikasi formalin sebanyak 25 sampel ikan secara kolorimetri menggunakan test kit MERCK. Berdasarkan pengelompokan jenis ikan asin didapatkan hasil positif sebesar $20 \%$ pada ikan asin teri jengki, dan 100\% pada ikan asin cucut, sedangkan untuk kategori ikan asin kapas, cumi, dan sepat tidak mengandung formalin. Kesimpulan dari penelitian ini adalah 24\% ikan asin yang beredar di Pasar Sederhana Kota Bandung positif mengandung formalin. Kelompok yang paling banyak mengandung formalin adalah ikan asin cucut.

Kata Kunci : formalin, ikan asin, keamanan pangan, pasar tradisional

\section{PENDAHULUAN}

Kesehatan merupakan salah satu komponen penting bagi kualitas hidup manusia, agar dapat hidup sehat, salah satu langkahnya adalah mengkonsumsi pangan yang aman dan bernutrisi. Pangan adalah hal yang sangat penting dan tidak dapat dipisahkan dari manusia karena pangan adalah kebutuhan primer. Kebutuhan primer seperti nutrisi didapat dari sumber makanan seperti nasi dan ikan. Ikan dapat diolah menjadi ikan asin dan merupakan sumber nutrisi yang banyak dikonsumsi oleh masyarakat Kota Bandung. Banyak kandungan zat bermanfaat yang bisa ditemukan pada ikan asin, beberapa zat yang bermanfaat bagi tubuh tersebut adalah kalsium, fosfor, zat besi, vitamin E, selenium, omega 3, asam lemak essensial, yang berguna untuk kesehatan gigi dan tulang, mencegah penyakit anemia, jantung, serta merawat kulit ( Hardoko et al., 2018).

Ikan cepat mengalami proses pembusukan. Sangat diperlukan tindakan yang tepat dan cermat dalam pencegahan pembusukan tersebut, mulai dari saat penangkapan sampai tiba di tangan konsumen. Pengawetan ikan bisa menggunakan cara tradisional, yaitu dengan metode penggaraman. Ikan asin merupakan produksi dari bahan ikan segar atau ikan setengah basah yang ditambah garam sekitar 15-20. Cara tradisional ini sendiri memiliki kekurangan saat proses pengawetan seperti terkendala pada saat musim penghujan. Ikan yang diproduksi akan mengalami pengeringan yang tidak sempurna dan berair. Proses penggaraman memakan waktu yang lama (sekitar 12-14 hari) dan ikan asin akan cepat mengalami kerusakan pada suhu di atas $15^{\circ} \mathrm{C}$. Selain itu, proses pengawetan ikan dapat dilakukan dengan menggunakan bahan tambahan pangan. Penggunaan bahan tambahan pangan 
pengawet yang diizinkan (seperti nitrat dan nitrit) harus sesuai dengan tujuan dan tidak melebihi batas yang telah diatur. Saat ini banyak produsen nakal yang menggunakan formalin sebagi bahan tambahan pangan untuk mengawetkan makanan, salah satunya pada ikan asin (Sutarni, 2013).

Penyalahgunaan bahan kimia berbahaya sebagai bahan tambahan pada produk makanan telah membuat resah masyarakat. Penggunaan bahan kimia berbahaya seperti pengawet formalin, digunakan oleh produsen pada produk makanan agar produk olahannya tersebut lebih tahan lama, dan lebih ekonomis, sehingga dapat menghasilkan keuntungan yang besar. Dampak kesehatan yang ditimbulkan dari penggunaan bahan berbahaya tersebut sangatlah buruk bagi masyarakat yang mengkonsumsinya.

Penggunaan formalin sebagai bahan pengawet makanan telah lama dilarang oleh pemerintah, hal ini dinyatakan pada Permenkes RI No.1168/Menkes/Per/X/1999. Formalin memiliki efek samping yang buruk pada kesehatan. Formalin dapat bereaksi cepat dengan lapisan lendir saluran pencernaan dan saluran pernafasan. Di dalam tubuh cepat teroksidasi membentuk asam format terutama di hati dan sel darah merah. Pemakaian pada makanan dapat mengakibatkan keracunan pada tubuh manusia, yaitu rasa sakit perut yang akut disertai muntahmuntah, timbulnya depresi susunan syaraf atau kegagalan peredaran darah, hingga bisa bersifat karsinogenik.

Melihat tingginya daya konsumsi ikan asin serta bahayanya formalin pada tubuh, maka Peneliti melakukan pengujian identifikasi formalin pada produk ikan asin yang beredar di Pasar Sederhana Kota Bandung dengan menggunakan test kit formalin dari Merck. Test kit tersebut akan membentuk senyawa (3,4,5,6dibenzoxanthylium) yang berwarna violet jika suatu sampel mengandung formalin, hal ini terjadi dikarenakan proses kondensasi senyawa fenol dengan formaldehida (Abdullah, 2013). Penelitian tentang formalin dianggap penting karena maraknya penggunaan zat pengawet berbahaya dalam produk ikan asin sehingga menyebabkan keraguan konsumen untuk mengkonsumsi produk tersebut. 


\title{
METODE
}

\begin{abstract}
Alat dan Bahan
Untuk peralatan yang digunakan pada pengujian ini antara lain gunting untuk memotong/memperkecil ukuran sampel, beaker glass $100 \mathrm{~mL}$ untuk wadah sampel yang ditambahkan aquadest, batang pengaduk, kertas saring dan corong untuk menyaring/memisahkan filtrat dari sampel, tabung reaksi untuk wadah filtrat dari sampel yang telah disaring, serta pereaksi formaldehyde test kit MERCK agar menunjukan terjadinya reaksi perubahan warna jika terdapat formalin pada sampel.

Untuk bahan yang digunakan pada pengujian ini antara lain sampel sampel ikan asin jengki, ikan asin kapas, ikan asin cumi, ikan asin cucut, ikan asin sepat, aquadest untuk melarutkan formalin yang terdapat pada sampel ikan asin, pereaksi Carez I, pereaksi Carez II untuk mengendapkan protein agar larutan menjadi jernih dan mudah diamati pada saat terjadi perubahan warna, formaldehyde test kit MERCK yang berisi pereaksi FO1 (larutan $\mathrm{NaOH}$ ) sebagai katalisator dan pereaksi FO2 yang berisi chromatropic sebagai pereaksi yang dapat membentuk warna violet jika terdapat formalin pada sampel.
\end{abstract}

\section{Rancangan Percobaan}

Jenis penelitian yang digunakan adalah deskriptif observasional dengan cara pengambilan sampel sebanyak 25 sampel ikan asin yang diduga mengandung formalin dengan ciri-ciri bertekstur keras, berwarna terang, dan tidak dihinggapi lalat. Sampel diambil langsung pada tanggal 17 Oktober 2020 dari pedagang dengan lima (5) ruko yang berbeda di setiap penjuru Pasar Sederhana Kota Bandung, adapun lima (5) kategori sampel ikan asin yang di-sampling yaitu ikan asin jengki, ikan asin kapas, ikan asin cumi, ikan asin cucut, ikan asin sepat.

\section{Prosedur Analisa Kualitiatif Formalin Dengan Menggunakan Formaldehyde Test Kit MERCK}

Mula-mula setiap sampel dikelompokan berdasarkan kategori dan diberi identitas, kemudian setiap sampel dipotong kecil-kecil dengan ukuran $\pm 1 \mathrm{~cm}^{2}$, dimasukan ke dalam beaker glass ukuran 100mL, dan ditambahkan air aquadest sebanyak $25 \mathrm{~mL}$ agar formalin yang terdapat pada sampel ikan asin ikut terlarut 
kedalam aquadest. Selanjutnya ditambahkan pereaksi penjernih sampel makanan yang berfungsi untuk mengendapkan protein yaitu Carrez 1 (mengandung Potassium hexacyanoferrate (II)) dan Carrez 2 (mengandung Zinc sulphate) masing-masing sebanyak $1 \mathrm{~mL}$, diaduk dan didiamkan selama 2 menit, kemudian filtrat diambil dengan cara dimasukan kedalam tabung pereaksi melalui kertas saring agar terpisah dari residu sampel ikan asin. Setelah filtrat didapat kemudian ditambahkan pereaksi FO1 $(\mathrm{NaOH})$ sebanyak 5 tetes, dan pereaksi FO2 (Chromatropic) sebanyak 1 sendok takar, dikocok, lalu didiamkan selama 5 menit.

Formalin dengan adanya asam cromatopat akan membentuk warna violet. Reaksi asam kromatropat mengikuti prinsip kondensasi senyawa fenol dengan formaldehyde membentuk senyawa berwarna (3,4,5,6-dibenzoxanthylium) seperti yang tertera pada Gambar 1 Pewarnaan disebabkan terbentuknya ion karbenium oksonium yang stabil karena mesomeri. Asam cromatopat digunakan untuk mengikat formalin agar terlepas dari bahan, reaksinya dipercepat dengan penambahan $\mathrm{NaOH}$.

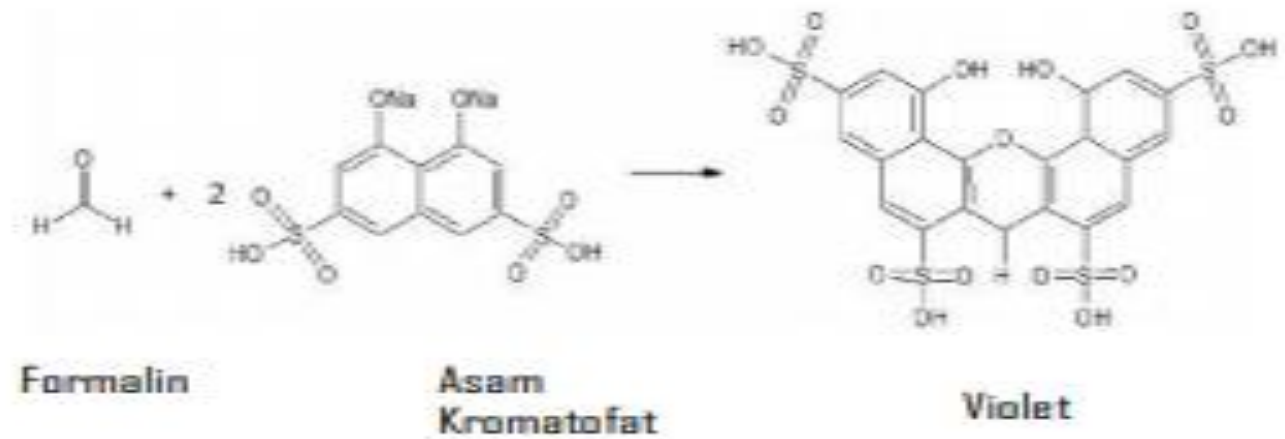

Gambar 1. Reaksi Formalin dan Kromatopat (Abdullah, 2013)

\section{HASIL DAN PEMBAHASAN}

Sebanyak 25 sampel ikan asin yang diduga mengandung formalin, disampling dari lima (5) ruko yang berbeda di setiap penjuru, yaitu pada bagian utara, barat, selatan, timur, dan pusat Pasar Sederhana Kota Bandung. Kategori sampel ikan asin yang di-sampling yaitu ikan asin jengki, ikan asin kapas, ikan asin cumi, ikan asin cucut, dan ikan asin sepat, karena dari sekian banyak jenis ikan asin, lima (5) jenis ikan tersebut memiliki ciri-ciri yang mencolok untuk dicurigai mengandung 
formalin, karena bertekstur keras, berwarna terang, dan tidak dihinggapi lalat. Dari pengujian formalin secara kualitatif yang dilakukan pada sampel ikan yang beredar di Pasar Sederhana Kota Bandung didapatkan hasil seperti yang tertera pada Tabel 1.

Tabel 1. Hasil Uji Formalin Pada Sampel Ikan Asin di Pasar Sederhana Kota Bandung

\begin{tabular}{cccccc}
\hline $\begin{array}{c}\text { Nama Ikan } \\
\text { Asin / } \\
\text { pedagang }\end{array}$ & Teri jengki & Kapas & Cumi & Cucut & Sepat \\
\hline Pedagang 1 & Negatif & Negatif & Negatif & Positif & Negatif \\
Pedagang 2 & Negatif & Negatif & Negatif & Positif & Negatif \\
Pedagang 3 & Positif & Negatif & Negatif & Positif & Negatif \\
Pedagang 4 & Negatif & Negatif & Negatif & Positif & Negatif \\
Pedagang 5 & Negatif & Negatif & Negatif & Positif & Negatif \\
\hline
\end{tabular}

Keterangan : Sampel yang dinyatakan positif mengandung formalin dapat diketahui dengan terjadinya perubahan warna larutan menjadi ungu violet setelah ditambahkan pereaksi dan didiamkan selama 5 menit. Sampel yang dinyatakan negatif / tidak mengandung formalin tidak mengalami perubahan warna / tidak terdapat warna ungu violet setelah ditambahkan pereaksi dan didiamkan selama 5 menit.

Semakin banyak formalin yang ditambahkan pada ikan asin, maka reaksi perubahan warnanya pun akan semakin pekat, dan berikut adalah dokumentasi hasil pengujian analisa kualitatif formalin pada sampel ikan asin yang beredar di Pasar Sederhana Kota Bandung :

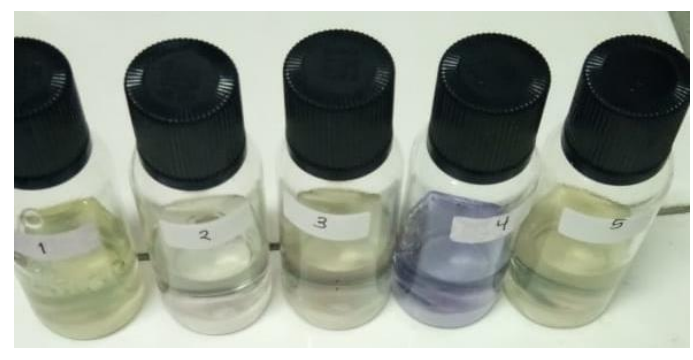

Pedagang 1

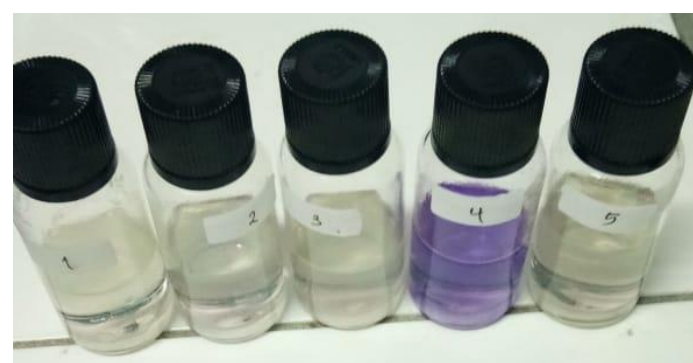

Pedagang 2 


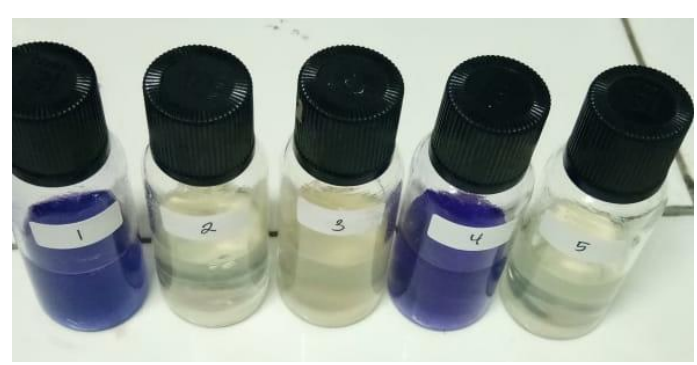

Pedagang 3

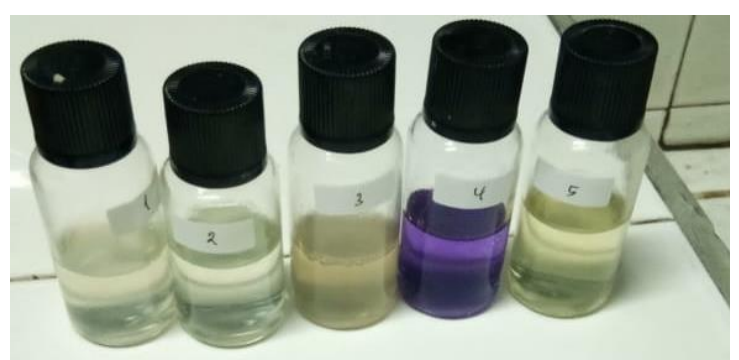

Pedagang 4

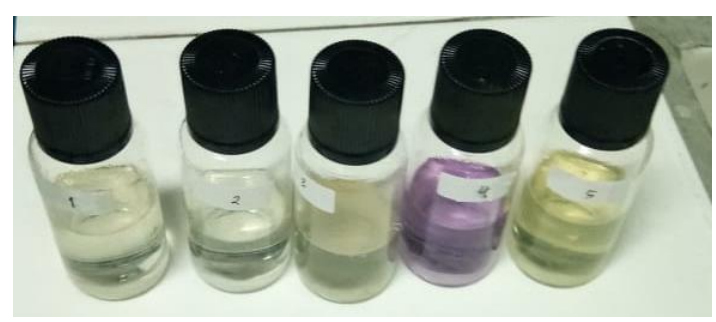

Pedagang 5

Setelah dilakukan pengujian dari seluruh sampel ikan asin yang disampling di pasar Sederhana Kota Bandung, ternyata hanya ikan asin teri jengki dan ikan asin cucut yang positif mengandung formalin, jika dibuat persentase dari keseluruhan sampel, maka terdapat $24 \%$ ikan asin mengandung formalin yang beredar di Pasar Sederhana Kota Bandung. Berdasarkan kategorinya, ikan asin teri jengki yang beredar di Pasar Sederhana Kota Bandung 20\% mengandung formalin, dan kategori ikan asin cucut $100 \%$ seluruhnya mengandung formalin, sedangkan untuk kategori ikan asin kopos, cumi, dan sepat tidak mengandung formalin.

Untuk mencegah mengkonsumsi ikan asin yang berformalin dipasaran sebaiknya konsumen lebih jeli jika ingin membeli ikan asin di pasar-pasar tradisional. Ketidaktahuan produsen dan pedagang, maupun tindakan sengaja dari produsen mengenai penggunaan formalin, dapat menjadi bahaya bagi konsumen di masa depan jika tidak segera dilakukan pencegahan, dengan karya ilmiah ini diharapkan dapat memberikan pengetahuan pada produsen dan pedagang mengenai bahan-bahan pengawet yang diperbolehkan maupun yang dilarang keberadaannya khusunya formalin pada produk ikan asin.

Diperlukan kehati-hatian dalam memilih ikan asin untuk dikonsumsi, hindari ikan asin yang memiliki ciri-ciri bertekstur keras, berwarna terang, dan tidak dihinggapi lalat. Salah satu cara untuk menanggulangi adanya formalin dalam ikan 
asin bisa dengan cara deformalinisasi / menghilangkan formalin dengan cara merendam ikan asin dengan air mendidih selama minimal 10 menit dan digoreng dengan menggunakan minyak panas. Dan untuk produsen perlu dilakukan penyuluhan dan edukasi mengenai bahaya formalin jika digunakan sebagai bahan pengawet pada makanan khusunya produk ikan asin, pengawetan dengan cara tradisional seperti proses pengeringan, dan penggaraman yang baik bisa dijadikan prioritas untuk membuat produk ikan asin yang tidak cepat busuk, selain itu penggunaan lemari es atau es batu dapat dilakukan untuk mengatur suhu agar tetap dibawah suhu $15^{\circ} \mathrm{C}$ agar dapat memperpanjang waktu penyimpanan.

\section{KESIMPULAN}

Hasil penelitian menunjukkan, dari 25 sampel yang di-sampling dari lima (5) pedagang yang berbeda, dinyatakan bahwa 24\% ikan asin di Pasar Sederhana Kota Bandung positif mengandung formalin. kategori ikan asin yang mengandung formalin tersebut adalah ikan asin teri jengki dan ikan asin cucut, sedangkan untuk kategori ikan asin kapas, cumi, dan sepat tidak mengandung formalin.

\section{SARAN}

Perlu dilakukan penyuluhan dan edukasi kepada konsumen dan produsen mengenai bahaya formalin jika digunakan sebagai bahan pengawet pada makanan khusunya produk ikan asin. Diperlukan kehati-hatian dalam memilih ikan asin untuk dikonsumsi, hindari ikan asin yang memiliki ciri-ciri bertekstur keras, berwarna terang, dan tidak dihinggapi lalat.

\section{DAFTAR PUSTAKA}

Abdullah, S. (2013). Uji Kualitatif Kandungan Formalin Pada Ikan Asin yang Dijual di Pasar Sentral Kota Gorontalo. Gorontalo. Universitas Negeri Gorontalo.

IKLP. (2015). Cara Uji Cepat Formalin. Bandung. Balai Besar Pengawas Obat dan Makanan di Bandung

Hardoko, Sasmito B.B., Puspitasari Y.E., Lilyani N. (2018). Konversi Ikan Asin Menjadi Nugget Berserat Pangan Dengan Tambahan Ampas Tahu Dan 
Food Scientia Journal of Food Science and Technology 1(1) 2021, 49-57

Beberapa Jenis Binder. Jurnal Pengolahan Hasil Perikanan Indonesia, 121 12(1)

Sutarni. (2013). Faktor-Faktor Yang Mempengaruhi Produksi Pengawetan Ikan Asin Teri Di Kecamatan Labuhan Maringgai Kabupaten Lampung Timur. Jurnal Ilmiah ESAI . 